\title{
A Study on the Process Oriented Evaluation System of Undergraduate Training Programs for Innovation and Entrepreneurship ${ }^{1}$
}

\author{
Yanyan Sheng1, Qiushan Yư ${ }^{2}$, Liyou Chen ${ }^{3}$ \\ ${ }^{1}$ School of Management, Yangtze University, Jingzhou, China \\ ${ }^{2}$ School of Physics and Optoelectronic Engineering, Yangtze University, Jingzhou, China \\ ${ }^{3}$ School of Economics, Yangtze University, Jingzhou, China \\ Email:louyougen@163.com
}

How to cite this paper: Sheng, Y. Y., Yu, Q. S., \& Chen, L. Y. (2016). A Study on the Process Oriented Evaluation System of Undergraduate Training Programs for Innovation and Entrepreneurship. Creative Education, 7, 2330-2337. http://dx.doi.org/10.4236/ce.2016.715225

Received: September 3, 2016

Accepted: September 24, 2016

Published: September 27, 2016

Copyright $\odot 2016$ by authors and Scientific Research Publishing Inc. This work is licensed under the Creative Commons Attribution International License (CC BY 4.0).

http://creativecommons.org/licenses/by/4.0/

\begin{abstract}
The current evaluation system of College Students' innovation and entrepreneurship training program is not conducive to the healthy development of the training project, such as heavy project, light process and fuzzy evaluation subject. In order to improve the implementation of the training program, process oriented evaluation system should be established, concluding indicators selected from initiation process, operation process and final process, and weights are calculated by Delphi method. Process management and classified criterion to finish process are suggested to improve the effectiveness of College Students' innovation and entrepreneurship training program.
\end{abstract}

\section{Keywords}

Process Oriented, College Students' Innovation and Entrepreneurship Training Program, Evaluation System

\section{Introduction}

Undergraduate Training Programs for Innovation and Entrepreneurship (hereinafter referred to as Daiso training program) is directly hosted by Chinese Ministry of Education, aiming at enhancing the practical capability of university students. However, al-

${ }^{1}$ Project supported by Humanities-Society Scientific research program of Hubei provincial education department (Research on promoting transformation of achievement of process-based undergraduate training program for innovation and entrepreneurship, No.16Q086), teaching research program of Yangtze university (research on Evaluation system for process-based undergraduate training program for innovation and entrepreneurship, No.JY2014026), Humanities-Society Scientific research program of Yangtze university (research on Evaluation system for achievements-based undergraduate training program for innovation and entrepreneurship, No.2015csy013). 
though most of Chinese universities have paid lots of attention to promoting the program, a so-called "emphasizing on outcomes while neglecting process" phenomenon has become very common but unwanted. As a result, students engaging in Daiso training program tend to pursue quick success and instant benefit, and lack in-depth research thinking and initiative to explore, thus lead to an ineffective result of Daiso training program (Wang \& Xie, 2012). Exploring the causes of this phenomenon, it may be related to its overemphasis on outcome in the current evaluation system of Daiso training program. Therefore, there is an urgent need to establish a processoriented evaluation system for Daiso training program.

At present, researches on the evaluation system of Daiso training program mainly focused on how to select the evaluation index. Current views can be generally categorized into three types: the first type only considers one participant in project evaluation. For example, Shao advised to build the evaluation system based on the duties of supervisors, such as supervisors' attitude, experience and capability (Shao et al., 2013). Qi proposed to evaluate from perspective of student, his evaluation system involved students' creativity, communication frequency, teamwork, and experiment conductions (Qi \& Lu, 2009). Wang advocated to include experimental conditions into evaluation system (Wang et al., 2013), while Jing stated that it was also useful to consider universities, enterprises, and the degree of coordination between universities and enterprises, as well as innovation as evaluation indicators (Jing et al., 2014). The second view believes the evaluation system should be composed of evaluations referring to multiple participants. For example, Du stated that the evaluation system of Daiso training program should include multiple participants such as supervisors, students and universities (Du \& Ye, 2013). Yang argued that the selection of evaluation index should be considered from the establishment of innovation team perspective (Yang et al., 2009). The third view suggested selecting evaluation index based on operating process of Daiso training program, and including multiple participants to conduct evaluation. Li argued to select evaluation index according to three stages, involving topic selection, implementation and outcomes. And in the topic selection stage, experts should be the raters, while supervisors should conduct evaluation in implementation stage, and in final outcome stage, students, supervisors and experts should be all involved (Li et al., 2010). Huo and his colleagues (2015) also pointed out that evaluation should not be limited and focused on the application and conclusion reviews, the whole process including the application, implementation and result presentation should be taken into account when selecting key evaluation indicators.

Previous researches have provided a variety of ideas concerning Daiso training project evaluation, as well as rating scales of the evaluation system, which laid a good foundation for further research in Daiso training program evaluation system. We find that most researchers conduct their evaluation focusing on only one participant, such method is simple and straightforward, but cannot help to solve the current "emphasizing on outcomes while neglecting process" problem (Du \& Ye, 2013; Yang et al., 2009). Lee and his colleagues therefore proposed a process-oriented evaluation system for 
Daiso training programs, which reduced above problem to a certain extent ( $\mathrm{Li}$ et al., 2010; Huo et al., 2015), but lacked a comprehensive evaluation system involving different participants, which might lead to a failure in distinguishing the duties between the various participants in each stage, and the rating scale they proposed might turn out to be not very practical. In view of the above-mentioned facts, we believe a processoriented, quantitative evaluation index system, which serves multiple evaluation bodies, could promote the development of evaluation system of Daiso training programs.

\section{Analysis of the Process Evaluation Index}

\subsection{Analysis of the Process Evaluation Index at Topic Selection Stage}

Evaluation in topic selection process refers to reviews on project feasibility conducted by a panel of experts, aiming at determining which projects to finance, and the funding quota, including reviews of project proposals and project application defense.

In topics selection process, quantitative evaluation is conducted focuses on students, supervisors and experimental conditions. Evaluation of students is mainly related to the innovativeness, feasibility and expected practical values of the project proposals, as well as students' knowledge and skill levels. Evaluation of supervisors focuses on supervisors' professional guiding capability and responsibility, such as, whether supervisor's background, field of study and research experience are relevant to the selected topics, and supervisor's work styles. Evaluation of experimental conditions refers to aspects involving laboratory equipment, materials, facilities and environment, as well as the process management. It especially focuses on whether the existing experimental conditions can meet the requirements of experiments, and whether there are alternative solutions when those requirements cannot be satisfied.

\subsection{Analysis of the Process Evaluation Index at Project Implementation Stage}

Evaluation in project implementation process refers to the process of students engaging in research projects under supervisor's guidance. The management party of the project supervises the process by mid-term examination, which is critical for the evaluation of Daiso training program.

In this stage, quantitative evaluation should be conducted involving three angles: 1) Evaluation of the students. Students are expected to conduct research in accordance with the preset goals and time schedule mentioned in project proposal. Evaluation of students should pay attention to students' problem solving capability, innovative methods adopting, effort commitment, progress of project implementation and experiment records and summary or introspection of training and outcomes. 2) Evaluation of the supervisor. In project implementation process, the tasks of supervisor involves guiding students to master proper research methods, inspiring students to think creatively, encouraging and guiding students to overcome difficulties, and helping students to learn from experience. Accordingly, evaluation of supervisors should take into account the number of supervisor's guidance, the extent to which that students accept to 
supervisor's heuristic teaching, and other aspects of supervisor's performance such as the degrees of innovative thinking, rationality of resource deployment. 3) Evaluation of the management. The main tasks of management party is to provide necessary space, material supports and process controls in order to ensure the smooth implementation of the project. Therefore, evaluation of management should consider the quality, quantity, timeliness and effective supervision of funds, space and equipment.

\subsection{Analysis of the Process Evaluation Index at Results Reporting Stage}

Evaluation in results reporting stage is the conclusive evaluation of the quality of Daiso training programs. In results reporting process, students are required to submit a project self-assessment report, project supervisor evaluate the team performance during the whole project, and project review panel conduct an overall evaluation on project results, including both a written review and a presentation evaluation. In particular, the written review adopts a peer review approach in line with the academic fields, while presentation evaluation requires a face-to-face defense concerning the implementation and results of the project.

Evaluation of results reporting process should focus on the performance of team members during the written review and presentation evaluation. Evaluation of written review mainly involves student's understanding of problem solving plans, the completion of project preset targets, innovation performance during problem solving process, writing skills, and supervisor's evaluation about the overall performance of students. The key elements of presentation evaluation involve student's elaboration on problem solving process of main issues, innovativeness of the solutions, degree of independence in research, teamwork capability, value of research results, and performance during the defense.

\section{Weights of Evaluation Scales}

\subsection{Sample and Procedures}

In design of evaluation index, researchers commonly use Delphi method to weight different indexes, so as to reflect the relative importance of different indicators. For project evaluation experts, we collected data from experts that have rich experience in guiding, evaluating and organizing of Daiso training programs, their opinions tend to have high reliability and validity. In order to enhance the representativeness, based on the "list of advanced units in 2014 National University Students Innovation and Entrepreneurship Training Program" from Chinese Ministry of Education, we selected four outstanding universities to conduct questionnaire survey (two universities directly under the Ministry of Education: Huazhong University of Science and Technology, Central South University; and two local universities: Hunan Normal University, Yangtze University).

The questionnaire is divided into three parts. The first part is personal information, including gender, age, education and university. The second part concerns the personal opinions on the proportions of topic selection, project implementation and results re- 
porting process in Daiso project evaluation, while the third part requires respondents to weight different indicators. Questionnaires are collected on-site, a total of 40 validated questionnaires are achieved.

\subsection{Calculation of the Weights}

In this research, weights of indicators are calculated using the weighted average method. Firstly, calculate the average scores. The weight of each secondary index $\left(U_{i j} i, j=\right.$ $1,2,3 \ldots)$ is the average score of 40 experts, and the weight of the first level index is obtained by aggregating the secondary index weights $\left(U_{p}, i=1,2,3 \ldots\right)$. Secondly, adjust the differences. Given that the second part of the questionnaire has provided the expert's evaluation of the first level indexes $\left(x_{i}, i=1,2,3 \ldots\right)$, the results may differ from the aggregated weights we have obtained. Hence, if there are differences, we calculate and use the average of $U_{i}$ and $x_{i}$ as the weight of the first level index. Thirdly, determine the final weight. For convenience, we use integer weights, and excluding indexes that weight less than $5 \%$.

\section{Establishing the Evaluation Index System}

Index system consists of indexes and weights. Due to the limits of the paper, a evaluation index system we proposed for Daiso training program (science and engineering category) is presented in three tables as follows (Tables 1-3).

Table 1. Structure of evaluation system of topic selection process (science and engineering in Daiso training project, $30 \%$ ).

\begin{tabular}{|c|c|c|c|}
\hline First level index & Secondary index & Weight & Main content \\
\hline & Background correlation $U_{11}$ & 25 & $\begin{array}{l}\text { Supervisor has relevant research background close to the } \\
\text { chosen topic }\end{array}$ \\
\hline $\begin{array}{l}\text { Supervisor ability } \\
\text { evaluation } U_{1}\end{array}$ & Academic and professional titles $U_{12}$ & 20 & Supervisor has senior title or Ph.D. degree \\
\hline \multirow[t]{4}{*}{$(0.10)$} & Professional skills $U_{13}$ & 25 & Supervisor has professional skills relevant to the chosen topic \\
\hline & Teaching demeanor $U_{14}$ & 30 & Supervisor has decent ethics and professionalism \\
\hline & Prior research foundation $U_{21}$ & 10 & $\begin{array}{c}\text { Members with a solid knowledge of relevant topic, have clear } \\
\text { research ideas }\end{array}$ \\
\hline & Topic innovativeness $U_{22}$ & 25 & $\begin{array}{l}\text { Scientificalness of the topic, innovativeness, has value to explore and } \\
\text { promote }\end{array}$ \\
\hline Student ability evaluation $U_{2}$ & Design of the project $U_{23}$ & 25 & Design reasonable, clear, workable \\
\hline \multirow[t]{3}{*}{$(0.15)$} & Expected results $U_{24}$ & 10 & $\begin{array}{l}\text { Clear targets, comparable test procedures and data, results have } \\
\text { practical value }\end{array}$ \\
\hline & Teamwork $U_{25}$ & 20 & Reasonable team composition and division, interdisciplinary \\
\hline & presentation $U_{26}$ & 10 & Statement clear, concise and logical \\
\hline $\begin{array}{l}\text { Experimental conditions } \\
\text { evaluation } U_{3}\end{array}$ & $\begin{array}{l}\text { experimental facilities and } \\
\text { the environment } U_{31}\end{array}$ & 30 & Facilities and environment meet the requirement of the topics \\
\hline \multirow[t]{2}{*}{$(0.05)$} & $\begin{array}{l}\text { Laboratory equipment and } \\
\text { materials } U_{32}\end{array}$ & 40 & $\begin{array}{l}\text { Laboratory instruments and materials meet the requirement of the } \\
\text { topics }\end{array}$ \\
\hline & Project management level $U_{33}$ & 30 & Good administration and professional personnel \\
\hline
\end{tabular}


Table 2. Structure of evaluation system of project implementing process (science and engineering in Daiso training project, $40 \%$ ).

\begin{tabular}{|c|c|c|c|}
\hline First level index & Secondary index & Weight & Main content \\
\hline & schedule execution $U_{41}$ & 10 & Clear experimental content and targets, progress in line with expectations \\
\hline & project completion quality $U_{42}$ & 20 & Design and conception correct, completing with high quality \\
\hline $\begin{array}{l}\text { Student performance } \\
\text { evaluation } U_{4}\end{array}$ & $\begin{array}{l}\text { Independent laboratory } \\
\text { capacity } U_{43}\end{array}$ & 20 & $\begin{array}{l}\text { Have capability to analyze, identify and solve problems, take the initiative to } \\
\text { gather literature, process information, acquire new knowledge and complete } \\
\text { experiment independently }\end{array}$ \\
\hline \multirow[t]{5}{*}{$(0.20)$} & $\begin{array}{l}\text { Independent innovation } \\
\text { capability } U_{44}\end{array}$ & 25 & $\begin{array}{l}\text { Provide improvements or breakthroughs to previous research, or present unique } \\
\text { insights/ideas, have innovative performance }\end{array}$ \\
\hline & Research Performance $U_{45}$ & 5 & $\begin{array}{c}\text { Capable to solve problems occurred in test process, achieve certain outcomes or } \\
\text { achievements }\end{array}$ \\
\hline & Teamwork $U_{46}$ & 10 & Good at adopting other's suggestions, active cooperation to complete the task \\
\hline & $\begin{array}{l}\text { daily record and } \\
\text { introspection } U_{47}\end{array}$ & 10 & Timely record, good at summing up, introspection with written records \\
\hline & Instructor style $U_{51}$ & 20 & High level of professionalism and communication willingness \\
\hline $\begin{array}{l}\text { Supervisor performance } \\
\text { evaluation } U_{5}\end{array}$ & Process innovativeness $U_{52}$ & 40 & Guiding with good inspiration and innovation \\
\hline \multirow[t]{3}{*}{$(0.10)$} & $\begin{array}{l}\text { Process quality } \\
\text { management } U_{53}\end{array}$ & 20 & Full participation in project, check and control process details \\
\hline & Professional skills $U_{54}$ & 10 & Show a strong level of expertise in guiding methods \\
\hline & $\begin{array}{l}\text { Resource allocation } \\
\text { management } U_{55}\end{array}$ & 10 & Rational use and deployment of resources in project implementation \\
\hline $\begin{array}{l}\text { Management services } \\
\text { evaluation } U_{6}\end{array}$ & $\begin{array}{l}\text { Project process } \\
\text { management } U_{61}\end{array}$ & 40 & Show effective supervision on project implementation schedule \\
\hline \multirow[t]{3}{*}{$(0.10)$} & Financing management $U_{62}$ & 25 & Provide financing timely, effective supervision on expenditure \\
\hline & $\begin{array}{l}\text { Site and equipment } \\
\text { management } U_{63}\end{array}$ & 25 & Provide necessary sites, ensure regular use of equipment \\
\hline & Process file management $U_{64}$ & 10 & Manage process files of each stage, update timely \\
\hline
\end{tabular}

Evaluation index in this paper is selected according to three stages, including topic selection, project implementation and result reporting. The overall scale is constituted by 8 first level indexes and 39 secondary indexes. Table 1 is evaluation system of topic selection process, there are 3 first level indexes including 13 secondary indexes, the weight of the 3 first level indexes is 30 percent. Table 2 is evaluation system of project implementation, there are 3 first level indexes including 16 secondary indexes, the weight of the 3 first level indexes is 40 percent. Table 3 is evaluation system of result reporting, there are 2 first level indexes including 10 secondary indexes, the weight of the 3 first level indexes is 30 percent.

The quantitative evaluation of each index can be described by the following formula:

$$
X=U_{1} \sum U_{1 i}+U_{2} \sum U_{2 i}+\cdots+U_{8} \sum U_{8 i}=\sum_{i=1}^{8} U_{i}\left(\sum U_{i j}\right)
$$

where in, $X$ represents the total score of the project implementation process, $U_{i}$ and $U_{i j}$ represent the first level and secondary index weights. 
Table 3. Structure of evaluation system of result reporting process (science and engineering in Daiso training project, $30 \%$ ).

\begin{tabular}{|c|c|c|c|}
\hline First level index & Secondary index & Weight & Main content \\
\hline & $\begin{array}{c}\text { Content } \\
\text { Innovativeness } U_{71}\end{array}$ & 20 & $\begin{array}{l}\text { Has certain innovation and difficulty in knowledge, technology and research methods, overall } \\
\text { research and main technical indicators have reached or approached the advanced level of similar } \\
\text { research projects, have objective analysis on outcomes that not reached the expected goals }\end{array}$ \\
\hline $\begin{array}{l}\text { Written concluding } \\
\text { report review and } \\
\text { evaluation } U_{7}\end{array}$ & $\begin{array}{l}\text { Research outcomes } \\
\qquad U_{72}\end{array}$ & 20 & $\begin{array}{l}\text { Present research works, including: actual objects, creative ideas, software, patents, or patent } \\
\text { application acceptance notice, published research papers }\end{array}$ \\
\hline \multirow[t]{3}{*}{$(0.15)$} & $\begin{array}{l}\text { Quality of research } \\
\text { outcomes } U_{73}\end{array}$ & 20 & Accurate data, research outcomes have certain academic and social application value \\
\hline & $\begin{array}{l}\text { Writing skills level } \\
\qquad U_{74}\end{array}$ & 15 & Correct discussion, with a clear rational, logical and strong writing skills \\
\hline & $\begin{array}{l}\text { Supervisor overall } \\
\text { evaluation } U_{75}\end{array}$ & 25 & $\begin{array}{l}\text { Have proper description and evaluation on overall performance of students in the process of } \\
\text { project and the quality of project implementation }\end{array}$ \\
\hline $\begin{array}{l}\text { Presentation } \\
\text { evaluation } U_{8}\end{array}$ & $\begin{array}{l}\text { key issue solution } \\
\qquad U_{81}\end{array}$ & 20 & $\begin{array}{l}\text { Unique understanding of key issues and techniques, address and solve problems, and have } \\
\text { objective analysis on unsolved problems }\end{array}$ \\
\hline \multirow[t]{4}{*}{$(0.15)$} & $\begin{array}{l}\text { Innovative } \\
\text { understanding } U_{82}\end{array}$ & 30 & $\begin{array}{l}\text { Has certain innovation and difficulty in knowledge, technology and research methods, overall } \\
\text { research and main technical indicators have reached or approached the advanced level of similar } \\
\text { research projects, have objective analysis on outcomes that not reached the expected goals }\end{array}$ \\
\hline & $\begin{array}{l}\text { Independence } \\
\text { performance } U_{83}\end{array}$ & 10 & Project mainly completed by group members independently \\
\hline & $\begin{array}{l}\text { team performance } \\
\qquad U_{84}\end{array}$ & 20 & Good at adopting other's suggestions, active cooperation to complete the task \\
\hline & $\begin{array}{l}\text { presentation } \\
\text { performance } U_{85}\end{array}$ & 20 & $\begin{array}{l}\text { Meet requirements for presentation, clear statements, answer questions correctly, concise and to } \\
\text { the point }\end{array}$ \\
\hline
\end{tabular}

\section{Conclusions}

The paper obtains the Process Oriented evaluation system of Undergraduate Training Programs for Innovation and Entrepreneurship. Through analyzing the process evaluation index at topic selection stage, project implementation stage and results reporting stage, we get 8 first level indexes and 39 secondary indexes. Then, Delphi method is used to weight different indexes by collecting data from experts. Finally, we get 3 tables by combining these indexes and weights, which is the Process Oriented evaluation system of Daiso training program.

Our research can be used in practice. It can be used to evaluate Daiso training program to find problems and verify who should undertake responsibility, then we know how to do better. If someone doesn't finish Daiso training program, but his evaluation is excellent, we can provide further support in fiancé, encourage him to put it off, even allow him to successfully end the program in order to encourage innovation.

There are two limitations in our research. The first one is that all indexes are researched by analyzing theoretically not empirically, so its reliability and validity need further confirmation. The second one is the small sample size; weight is calculated by scores rated by 40 experts from four universities. Though we avoid wrongs by choosing experts from different universities which are excellent in Daiso training program evalu- 
ation, their representativeness is also a problem.

\section{References}

Du, X. Q., \& Ye, X. Y. (2013). University Students' Innovative Ability Development Based on Students' Innovative Experimental Projects. Heilongjiang Education (Higher Education Research \& Appraisal), No. 1, 47-48.

Huo, L. S., Zhang, L. L., \& Xiang, L. N. (2015). Study on Process Management of University Students Innovative Training Program. China Market Marketing, No. 28, 142-143.

Jing, T., Zheng, Y. J. \& Tian, J. Z. (2014). Study of Postgraduates' Innovative Experiment Evaluation System in Perspective of Industry-University-Research. Experimental Technology and Management, 31, 169-172.

Li, D., Zhao, X. W., \& Wu, J. H. (2010). A Study on Process-Oriented Evaluation System of Innovative Experiment Project for College Students. Research in Higher Education of Engineering, No. 1, 102-104.

Qi, S. J., \& Lu, S. L. (2009). Discussion and Practical Issue of the Students in University Students Innovation Experiment Program. Experimental Technology and Management, 26, 29-31.

Shao, J., Dong, T., \& Wang, W. (2013). Assessment and Evaluation Research on Supervisors of University Students Innovation Experiment Program. Higher Education of Science, No. 6, 46-49, 76.

Wang, Y. X., \& Xie, L. Q. (2012). Experiences on Supervising National University Students Innovation Experiment Program. Laboratory Science, 15, 206-208.

Wang, Z., Du, Y. H., \& Liu, W. W. (2013). Discussion on Laboratory Construction from the University Student Innovative Experiment Perspective. Research and Exploration in Laboratory, 32, 287-289.

Yang, J. X., Wu, D. C. \& Peng, R. M. (2009). Constructing the Team Evaluation System Used in Innovative Experiment. Science \& Technology Information, No. 17, 77-78.

Submit or recommend next manuscript to SCIRP and we will provide best service for you:

Accepting pre-submission inquiries through Email, Facebook, LinkedIn, Twitter, etc.

A wide selection of journals (inclusive of 9 subjects, more than 200 journals)

Providing 24-hour high-quality service

User-friendly online submission system

Fair and swift peer-review system

Efficient typesetting and proofreading procedure

Display of the result of downloads and visits, as well as the number of cited articles

Maximum dissemination of your research work

Submit your manuscript at: http://papersubmission.scirp.org/

Or contact ce@scirp.org 